\title{
PENGARUH SISTEM RESIRKULASI TERHADAP KUALITAS AIR, KELULUSHIDUPAN BENIH IKAN GURAME (Osphronemus goramy), SERTA KELAYAKAN USAHA
}

\author{
THE EFFECT OF RECIRCULATION SYSTEM TO WATER QUALITY, SURVIVAL \\ RATE OF HATCHLING FISH OF GIANT GOURAMI (Osphronemus goramy), AND \\ BUSINESS FEASIBILITY
}

\author{
Fernando Jongguran Simanjuntak ${ }^{1,3}$, Kukuh Nirmala ${ }^{2}$, Ernik Yuliana ${ }^{3 *}$ \\ ${ }^{1}$ Balai Perikanan Budidaya Air Tawar Tatelu, Minahasa Utara, Sulawesi Utara \\ ${ }^{2}$ Departemen Budidaya Perairan, Fakultas Perikanan dan Ilmu Kelautan, IPB University \\ ${ }^{3}$ Program Studi Magister Manajamen Perikanan, Program Pascasarjana, Universitas Terbuka
}

Teregistrasi I tanggal: 30 Agustus 2020; Diterima setelah perbaikan tanggal: 14 Januari 2021; Disetujui terbit tanggal: 24 Januari 2021

\begin{abstract}
ABSTRAK
Salah satu komoditas ikan air tawar yang menyumbang produksi perikanan terbesar adalah ikan gurame (Osphronemus goramy) yang mempunyai nilai ekonomis tinggi. Pembenihan ikan gurame adalah hal yang penting untuk menjaga keberlanjutan budidaya ikan gurame. Tujuan penelitian adalah menganalisis pengaruh sistem resirkulasi terhadap kualitas air, kelulushidupan benih ikan gurame, dan kelayakan usaha. Pembenihan ikan gurame pada penelitian ini menggunakan tiga wadah budidaya, yaitu: 1) akuarium dengan sistem resirkulasi (Wadah I);2) kolam beton sistem air mengalir (Wadah II); kolam beton sistem pergantian air 30\% secara berkala (Wadah III). Parameter yang diamati meliputi kualitas air dan angka kelulushidupan benih ikan gurame, serta kelayakan usahanya. Hasil penelitian menunjukkan bahwa pemeliharaan benih ikan gurame pada akuarium dengan sistem resirkulasi mempunyai kualitas air (suhu, oksigen terlarut, dan amoniak) yang terbaik, angka kelulushidupan (average daily growth, average body weight, specific growth ratio, survival rate) yang terbaik, dan membutuhkan modal terbesar pada investasi awal tetapi menghasilkan keuntungan yang lebih tinggi. Pembenihan ikan gurame dengan sistem resirkulasi direkomendasikan karena meningkatkan kualitas air, menghasilkan tingkat kelulushidupan yang tinggi dan menghasilkan keuntungan yang lebih tinggi.
\end{abstract}

Kata kunci: benih gurame, kelayakan usaha, kualitas air, resirkulasi

\begin{abstract}
One of the freshwater fish commodities that contributes to the largest fisheries production is giant gourami (Osphronemus goramy) which has high economic value. Giant gourami hatchling is important to maintain the sustainability of its cultivation. This study aims to analyze the effect of recirculation system to water quality, survival rates, and feasibility of giant gourami hatchling business. Giant gourami hatchling in this study uses three cultivation containers, namely: 1) an aquarium with a recirculation system (Container I); 2) concrete pond with flowing water system (Container II); concrete pond with $30 \%$ water change system periodically (Container III). The parameters observed included water quality and survival rate of giant gourami hatchling, as well as the feasibility of their business. The results indicated that the giant gourami hatchling in an
\end{abstract}

Korespondensi Penulis:

*E-mail: ernik@ecampus.ut.ac.id

DOI: http://dx.doi.org/10.15578/plgc.v2i1.9303 
aquarium with a recirculation system had the best water quality (temperature, dissolved oxygen, and ammonia), had the best survival rate (average daily growth, average body weight, specific growth ratio, survival rate), and requires the largest amount of capital in the initial investment but yields more returns. Giant gouramy hatchery with a recirculation system is recommended due to improves water quality, results in a high survival rate and generates higher profits.

Keywords: giant gourami hatchling, business feasibility, water quality, recirculation

\section{PENDAHULUAN}

Ikan gurame banyak diminati oleh masyarakat dan mempunyai pangsa pasar yang tinggi sehingga budidaya ikan gurame memiliki prospek yang tinggi. Harga ikan gurame relatif tinggi, namun tetap diminati masyarakat karena cita rasa dagingnya yang istimewa. Budidaya ikan gurame dapat dilaksanakan dengan teknologi yang sederhana sampai teknologi modern. Sumber daya yang digunakan dalam budidaya ikan gurame cukup hemat, baik dari segi lahan maupun air yang diperlukan. Hal-hal tersebut membuat budidaya ikan gurame layak diandalkan sebagai usaha yang menjanjikan di bidang perikanan.

Nugroho (2008) berpendapat bahwa untuk mewujudkan budidaya ikan gurame menjadi usaha yang dapat diandalkan, diperlukan ketersediaan benih yang kontinyu baik dari segi jumlah maupun kualitas. Banyak kegiatan usaha budidaya ikan gurame tidak dapat berlanjut akibat tidak tersedianya benih. Permintaan benih ikan gurame mengalami peningkatan dari tahun 2000-2004 dengan rata-rata peningkatan mencapai $42,24 \%$ per tahun, tetapi kebutuhan ini belum dapat dipenuhi. Beberapa masalah yang sering ditemui pada usaha pembenihan ikan gurame adalah angka kematian yang tinggi, rendahnya fekunditas, serta ukuran benih yang tidak seragam. Oleh karena itu diperlukan suatu cara untuk mengatasi masalah-masalah tersebut, salah satunya adalah dengan menerapkan teknologi yang lebih tepat dan aplikatif pada usaha pembenihan ikan gurame.

Tujuan penelitian adalah menganalisis pengaruh sistem resirkulasi terhadap kualitas air, angka kelulushidupan benih ikan gurame, dan kelayakan usaha pembenihan ikan gurame. Penelitian dilakukan pada pembenihan ikan gurame dengan tiga wadah budidaya yang berbeda.

\section{METODE}

Penelitian dilaksanakan pada bulan Juni-Desember 2018 di Balai Perikanan Budidaya Air Tawar (BPBAT) Tatelu, Jl. Pinilih Jaga VI, Desa Tatelu, Kecamatan Dimembe, Kabupaten Minahasa Utara, Provinsi Sulawesi Utara. Objek penelitian adalah larva ikan gurame berukuran 0,5-1 $\mathrm{cm}$ dengan berat rata-rata $0,5 \mathrm{~g}$ yang berasal dari hasil produksi BPBAT Tatelu sebanyak 812.448 ekor. Alat yang digunakan meliputi akuarium berukuran $60 \times 40 \times 40 \mathrm{~cm}$, selang aerator, batu aerasi, set sistem resirkulasi (pipa paralon, pompa, heater, UV light, filter fisika, filter kimia, reservoir), kolam beton berukuran $4 \times 3 \times 1 \mathrm{~m}$, timbangan digital $(0,01 \mathrm{~g})$, penggaris $(0,1 \mathrm{~cm})$, ember, seser, waring, happa, sikat, kain lap, alat sipon, multiparameter meter, DO meter, spektrofotometer, pipet ukur, gelas percobaan amoniak, gunting, kamera, dan alat tulis. Bahan yang digunakan adalah benih ikan gurame, air kolam, tisu, sarung tangan, masker, amoniak test kit, larutan blanko (aquades), dan larutan kalibrasi $\mathrm{pH}$.

Penelitian dilakukan dengan
memelihara benih ikan gurame menggunakan: a) Wadah I, akuarium sistem resirkulasi; b) Wadah II, kolam beton sistem air mengalir; c) Wadah III, kolam beton sistem pergantian air 30\% secara berkala. Pemeliharaan benih ikan 
gurame dilakukan selama 30 hari dengan pemberian pakan berupa cacing tubifex secara at satiation. Analisis data yang digunakan adalah analisis statistik untuk membandingkan tingkat kelulushidupan benih ikan gurame pada tiga wadah pemeliharaan. Analisis usaha dilakukan untuk mengetahui kelayakan usaha pembenihan ikan gurame dalam tiga wadah budidaya.

\section{HASIL DAN BAHASAN \\ HASIL}

Suhu

Berdasarkan hasil pengamatan suhu diketahui bahwa suhu pada pagi hari yang terendah ditunjukkan oleh Wadah II yakni berkisar antara $24,1-24,2^{\circ} \mathrm{C}$ dan paling tinggi pada Wadah I yang berkisar antara $29,4-29,6^{\circ} \mathrm{C}$. Pada waktu sore hari ditunjukkan nilai suhu yang paling rendah oleh Wadah III dengan nilai kisaran 25,3$26,7^{\circ} \mathrm{C}$ dan paling tinggi ditunjukkan oleh Wadah I dengan nilai kisaran 29,7$30,1^{\circ} \mathrm{C}$. Perbandingan rata-rata suhu pada tiga wadah budidaya dapat dilihat pada Gambar 1.

$p H$

Berdasarkan hasil pengamatan $\mathrm{pH}$ diketahui bahwa nilai $\mathrm{pH}$ pada pagi hari yang terendah ditunjukkan oleh Wadah II yakni berkisar antara 6,2-7,0 dan paling tinggi pada Wadah III yang berkisar antara 7,0-7,2. Pada waktu sore hari, nilai $\mathrm{pH}$ terendah ditunjukkan oleh Wadah II dengan nilai kisaran 5,8-7,2 dan paling tinggi ditunjukkan oleh Wadah I dengan nilai kisaran 7,4-7,8. Perbandingan ratarata $\mathrm{pH}$ pada tiga wadah budidaya dapat dilihat pada Gambar 2.

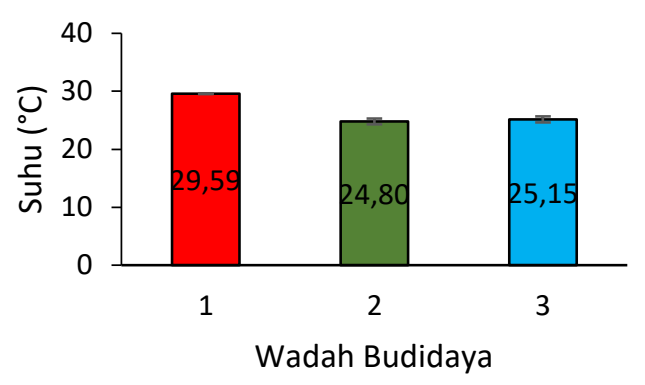

Gambar 1. Rata-rata suhu pada tiga wadah budidaya

(Ket: 1) akuarium sistem resirkulasi; 2) kolam beton sistem air mengalir; 3) kolam beton sistem pergantian air $30 \%$ secara berkala)

Figure 1. Temperature average of the three aquaculture containers

(Notes: 1) aquarium with recirculation system; 2) concrete pond with running water system; 3 ) concrete pond with $30 \%$ water change system at regular intervals) 


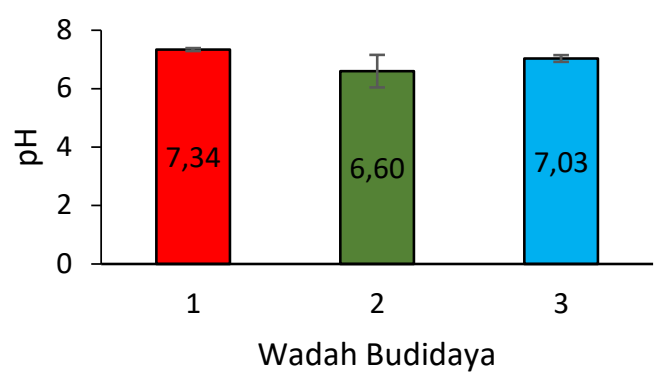

Gambar 2. Rata-rata $\mathrm{pH}$ pada tiga wadah budidaya

(Ket: 1) akuarium sistem resirkulasi; 2) kolam beton sistem air mengalir; 3) kolam beton sistem pergantian air $30 \%$ secara berkala)

Figure 2. pH average of the three aquaculture containers

(Notes: 1) aquarium with recirculation system; 2) concrete pond with running water system; 3) concrete pond with $30 \%$ water change system at regular intervals)

Dissolved Oxygen (DO)

Berdasarkan hasil pengamatan DO, diketahui bahwa nilai DO pada pagi hari yang terendah ditunjukkan oleh Wadah III yakni berkisar antara 4,1-4,4 ppm dan paling tinggi pada Wadah I yang berkisar antara 6,1-6,6 ppm. Pada waktu sore hari, nilai DO yang terendah ditunjukkan oleh Wadah III dengan nilai kisaran 4,3-4,5 ppm dan paling tinggi ditunjukkan oleh Wadah I dengan nilai kisaran 6,2-7,0 ppm. Perbandingan rata-rata nilai DO pada tiga wadah budidaya dapat dilihat pada Gambar 3.

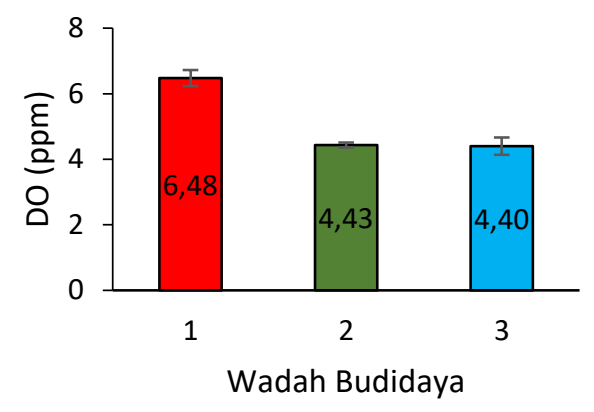

Gambar 3. Rata-rata DO pada tiga wadah budidaya

(Ket: 1) akuarium sistem resirkulasi; 2) kolam beton sistem air mengalir; 3) kolam beton sistem pergantian air $30 \%$ secara berkala)

Figure 3. DO average of the three aquaculture containers

(Notes: 1) aquarium with recirculation system; 2) concrete pond with running water system; 3) concrete pond with $30 \%$ water change system at regular intervals)

\section{Amoniak}

Berdasarkan hasil pengamatan terhadap kandungan amoniak, maka diketahui bahwa kisaran nilai amoniak pada pagi hari yang terendah ditunjukkan oleh Wadah I yakni berkisar antara 0,020,05 ppm dan paling tinggi pada Wadah III yang berkisar antara 0,42-0,51 ppm. Pada waktu sore hari, nilai amoniak yang paling rendah ditunjukkan oleh Wadah I dengan nilai kisaran 0,02-0,05 ppm dan paling tinggi ditunjukan oleh Wadah III dengan nilai kisaran 0,38-0,44 ppm. Perbandingan rata-rata amoniak pada tiga wadah budidaya dapat dilihat pada Gambar 4. 


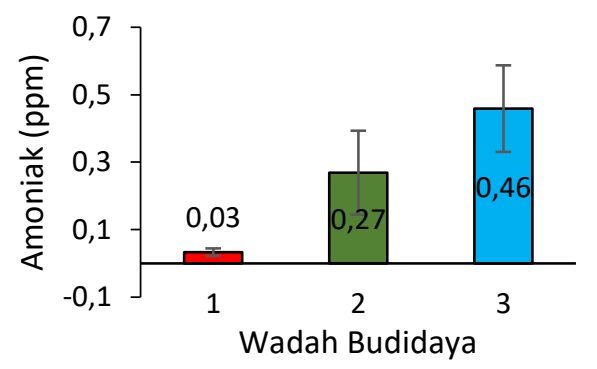

Gambar 4. Rata-rata amoniak pada tiga wadah budidaya

(Ket: 1) akuarium sistem resirkulasi; 2) kolam beton sistem air mengalir; 3) kolam beton sistem pergantian air $30 \%$ secara berkala)

Figure 4. Ammonia average of the three aquaculture containers

(Notes: 1) aquarium with recirculation system; 2) concrete pond with running water system; 3) concrete pond with $30 \%$ water change system at regular intervals)

Average Daily Growth (ADG)

Berdasarkan hasil pengukuran ADG diketahui bahwa Wadah I menunjukkan hasil pengukuran ADG yang paling tinggi yakni dengan nilai rata-rata $0,0425 \pm$
0,0050 g/hari, dan Wadah III menunjukkan hasil yang paling rendah yaitu dengan nilai rata-rata sebesar 0,0208 $\pm 0,00382 \mathrm{~g} / \mathrm{hari}$. Perbandingan rata-rata ADG pada tiga wadah budidaya dapat dilihat pada Gambar 5.

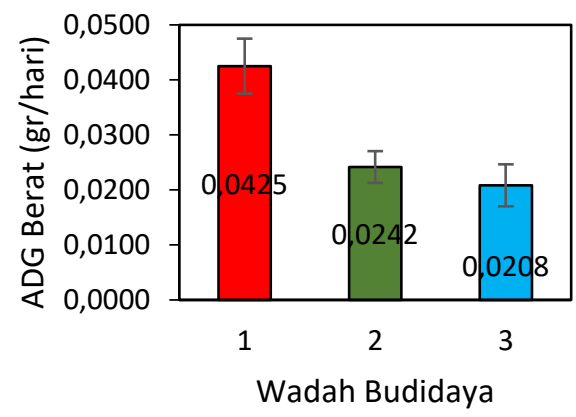

Gambar 5. Rata-rata pertumbuhan harian pada tiga wadah budidaya

(Ket: 1) akuarium sistem resirkulasi; 2) kolam beton sistem air mengalir; 3) kolam beton sistem pergantian air $30 \%$ secara berkala)

Figure 4. Avearage daily growth (ADG) of the three aquaculture containers

(Notes: 1) aquarium with recirculation system; 2) concrete pond with running water system; 3 ) concrete pond with $30 \%$ water change system at regular intervals)

\section{Average Body Weight (ABW)}

Berdasarkan penghitungan $\mathrm{ABW}$, diketahui Wadah I menunjukkan hasil yang paling tinggi yaitu rata-rata 2,20 \pm
$0,20 \mathrm{~g}$, dan Wadah III menunjukkan hasil yang paling rendah yaitu rata-rata sebesar $1,33 \pm 0,153 \mathrm{~g}$. Perbandingan rata-rata data $\mathrm{ABW}$ pada tiga wadah dapat dilihat pada Gambar 6. 


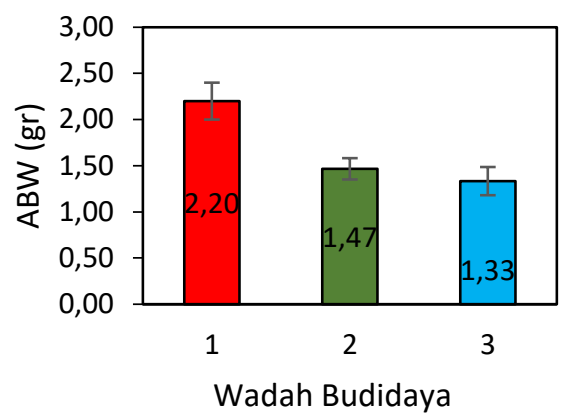

Gambar 6. Rata-rata ABW pada tiga wadah budidaya

(Ket: 1) akuarium sistem resirkulasi; 2) kolam beton sistem air mengalir; 3) kolam beton sistem pergantian air $30 \%$ secara berkala)

Figure 6. Avearage body weight $(A B W)$ of the three aquaculture containers

(Notes: 1) aquarium with recirculation system; 2) concrete pond with running water system; 3) concrete pond with $30 \%$ water change system at regular intervals)

Specific Growth Ratio (SGR)

Berdasarkan hasil penghitungan SGR, diketahui bahwa Wadah I menunjukkan hasil pengukuran SGR yang paling tinggi yaitu rata-rata $5,67 \pm 0,67 \%$, dan Wadah III menunjukkan hasil yang paling rendah yaitu rata-rata sebesar 2,78 $\pm 0,51 \%$. Perbandingan rata-rata nilai SGR pada tiga wadah budidaya dapat dilihat pada Gambar 7.

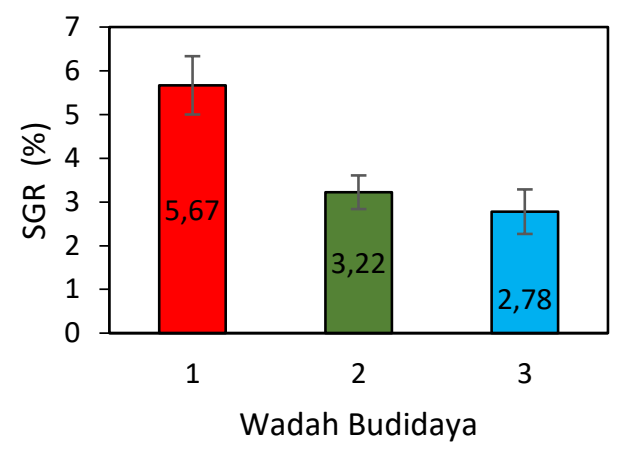

Gambar 7. Rata-rata SGR pada tiga wadah budidaya

(Ket: 1) akuarium sistem resirkulasi; 2) kolam beton sistem air mengalir; 3) kolam beton sistem pergantian air $30 \%$ secara berkala)

Figure 7. Avearage of specific growth ratio (SGR) of the three aquaculture containers

(Notes: 1) aquarium with recirculation system; 2) concrete pond with running water system; 3) concrete pond with $30 \%$ water change system at regular intervals)

\section{Survival Rate (SR)}

Berdasarkan hasil penghitungan SR, diketahui bahwa Wadah I menunjukkan hasil pengukuran SR yang paling tinggi yaitu rata-rata 95,07 $\pm 0,57 \%$, dan Wadah
III menunjukkan hasil yang paling rendah yaitu rata-rata $52,05 \pm 1,49 \%$. Perbandingan rata-rata SR pada tiga wadah budidaya dapat dilihat pada Gambar 8. 


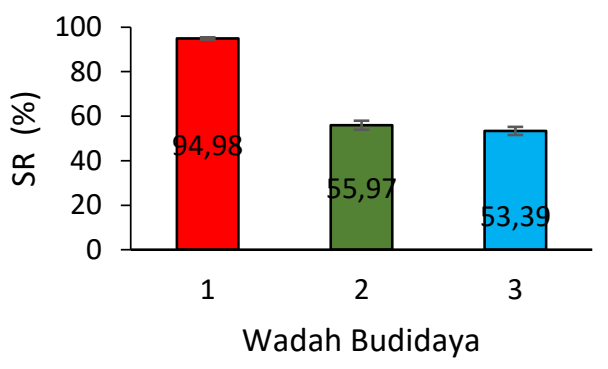

Gambar 8. Rata-rata SR pada tiga wadah budidaya

(Ket: 1) akuarium sistem resirkulasi; 2) kolam beton sistem air mengalir; 3) kolam beton sistem pergantian air $30 \%$ secara berkala)

Figure 8. Avearage of survival rate (SR) of the three aquaculture containers

(Notes: 1) aquarium with recirculation system; 2) concrete pond with running water system; 3) concrete pond with $30 \%$ water change system at regular intervals)

\section{Analisis Usaha}

Analisis kelayakan usaha pembenihan ikan gurame dilakukan untuk tiga wadah budidaya. Komponen biaya investasi, operasional, dan penjualan diambil dari harga-harga yang berlaku di Provinsi Sulawesi Utara. Hasil penghitungan analisis usaha untuk sistem resirkulasi pada akuarium dapat dilihat pada Tabel 1.

Dari hasil penghitungan pada Tabel 1 dapat dilihat bahwa pembenihan dengan sistem resirkulasi memerlukan investasi sebesar Rp33.600.000,00. Jika skala produksi dioptimalkan maka akan mampu memelihara 30.000 ekor larva gurame dengan besaran biaya operasional sebesar Rp12.268.889,00. Jika pemeliharaan selama dua bulan diperoleh SR sebesar 95\% dengan harga jual Rp800,00 maka diperoleh laba sebesar Rp10.531.111,00 atau Rp5.265.555,00 per bulan. Jika dibandingkan nilai upah minimum regional (UMR) Provinsi Sulawesi Utara sebesar Rp3.090.000,00 maka pendapatan dari usaha pembenihan gurame dengan sistem resirkulasi masih di atas nilai UMR. Nilai payback period sebesar 1,5 artinya modal yang dikeluarkan untuk usaha pembenihan dengan sistem resirkuasi dapat dikembalikan dalam waktu 1,5 tahun. Nilai revenue cost $(R C)$ ratio pada perhitungan menunjukan angka lebih besar dari 1 yaitu 1,85 sehingga usaha ini cukup layak dilaksanakan. Nilai break event point (BEP) yang diperoleh sebesar Rp430,00.

Tabel 2 menyajikan analisis usaha pembenihan ikan gurame pada bak beton dengan sistem air mengalir, yaitu memerlukan investasi sebesar Rp6.650.000, 00. Jika skala produksi dioptimalkan maka akan mampu memelihara sebanyak 134.400 ekor larva gurame dengan besaran biaya operasional sebesar Rp36.040.000,00. Jika pemeliharaan selama dua bulan di peroleh SR sebesar 58\% dengan harga jual Rp550,00 maka diperoleh laba sebesar Rp6.639.433,00 atau Rp3.139.717,00 perbulan. Nilai BEP perbenihan gurame dengan sistem ini sebesar Rp465,00. Nilai payback period sebesar 0,2 artinya modal yang keluarkan untuk usaha perbenihan gurame di bak beton dengan sistem air mengalir dapat dikembalikan dalam waktu 0,2 tahun. Nilai $R C$ ratio pada penghitungan menunjukan nilai yang lebih besar dari 1 yaitu 1,18 sehingga usaha ini cukup layak dilaksanakan.

Tabel 3 menyajikan analisis usaha pembenihan ikan gurame pada bak beton dengan sistem pergantian air 30\% secara berkala, yaitu memerlukan investasi sebesar Rp6.650.000,00. Jika skala produksi dioptimalkan maka akan mampu memelihara sebanyak 134.400 ekor larva 
gurame dengan besaran biaya operasional sebesar Rp36.234.167,00. Jika pemeliharaan selama dua bulan di peroleh SR sebesar 52\% dengan harga jual Rp550,00 maka diperoleh laba sebesar Rp2.204.233,00 atau Rp1.102.117,00 per bulan. Nilai BEP perbenihan gurame dengan sistem ini sebesar Rp518,00. Nilai payback period sebesar 0,2 artinya modal yang keluarkan untuk usaha perbenihan gurame di bak beton dengan sistem air mengalir dapat dikembalikan dalam waktu 0,2 tahun. Nilai $R C$ ratio pada penghitungan menunjukkan angka lebih besar dari 1 yaitu 1,06 .

Tabel 1. Analisis usaha perbenihan ikan gurame dengan sistem resirkulasi

Table 1. Business analysis of giant gouramy hatchling with recirculation system

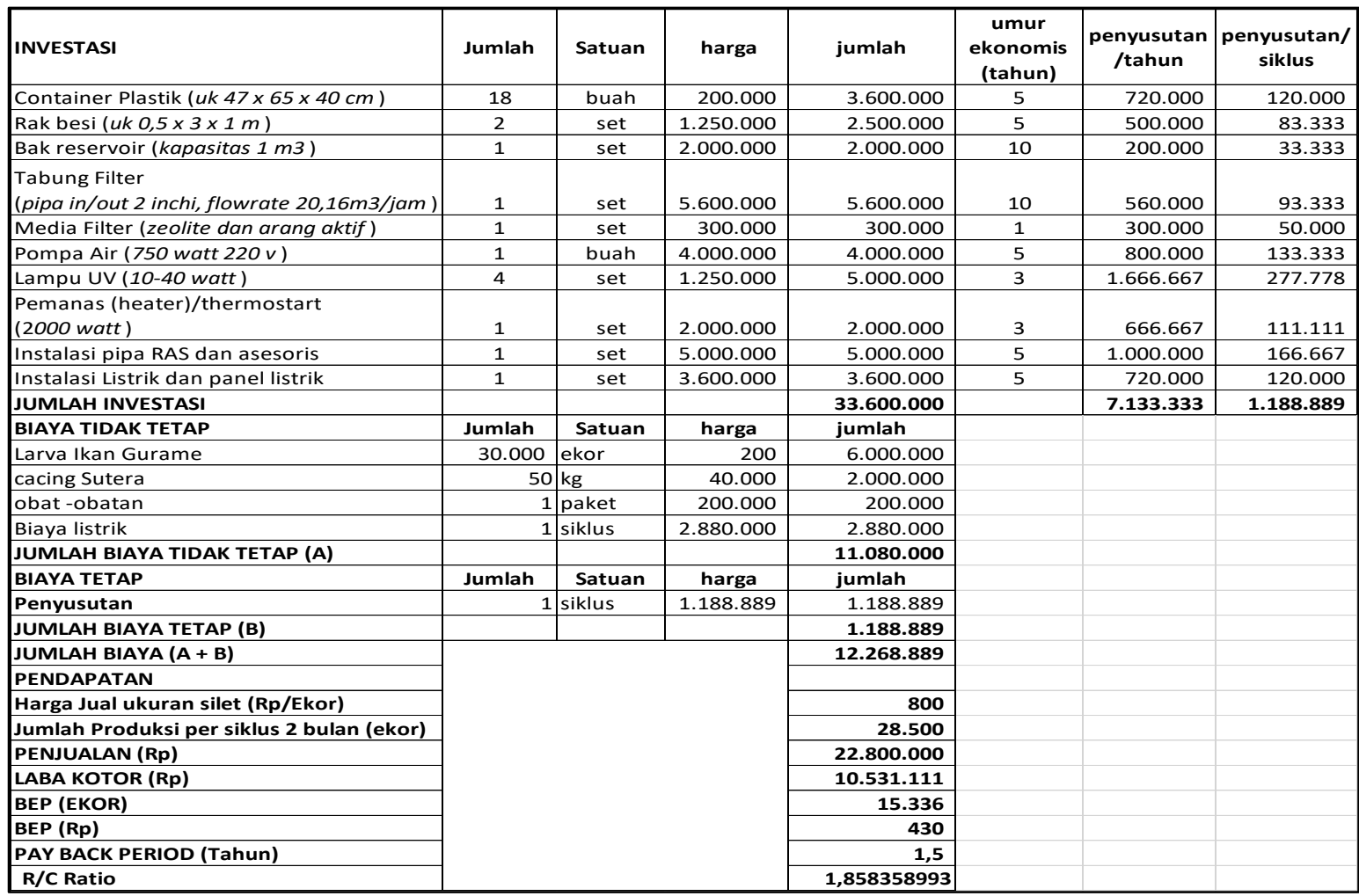


PELAGICUS: Jurnal IPTEK Terapan Perikanan dan Kelautan

Volume 2 Nomor 1: 23-35, Januari 2021

Tabel 2. Analisis usaha perbenihan ikan gurame di bak beton dengan sistem air mengalir Table 2. Business analysis of giant gouramy hatchling in a concrete pond with running water system

\begin{tabular}{|c|c|c|c|c|c|c|c|c|}
\hline A & INVESTASI & Jumlah & Satuan & harga & jumlah & $\begin{array}{c}\text { umur } \\
\text { ekonomis } \\
\text { (tahun) }\end{array}$ & $\begin{array}{c}\text { penyusutan } \\
/ \text { tahun }\end{array}$ & $\begin{array}{c}\text { penyusutan/ } \\
\text { siklus }\end{array}$ \\
\hline 1 & Pembuatan bak beton uk $4 \times 3 \times 0.5 \mathrm{~m}$ & 1 & unit & 1.650 .000 & 1.650 .000 & 10 & 165.000 & 27.500 \\
\hline 2 & Instalasi pipa dan asesoris & 1 & set & 5.000 .000 & 5.000 .000 & 5 & 1.000 .000 & 166.667 \\
\hline & JUMLAH INVESTASI & & & & 6.650 .000 & & 1.165 .000 & 194.167 \\
\hline B & BIAYA TIDAK TETAP & Jumlah & Satuan & harga & jumlah & & & \\
\hline 1 & Larva Gurame & 134.400 & ekor & 200 & 26.880 .000 & & & \\
\hline 2 & cacing Sutera & 224 & $\mathrm{~kg}$ & 40.000 & 8.960 .000 & & & \\
\hline 3 & obat -obatan & 1 & paket & 200.000 & 200.000 & & & \\
\hline & JUMLAH BIAYA TIDAK TETAP & & & & 36.040 .000 & & & \\
\hline C & BIAYA TETAP & Jumlah & Satuan & harga & jumlah & & & \\
\hline \multirow{4}{*}{1.} & Penyusutan & 1 & siklus & 194.167 & 194.167 & & & \\
\hline & JUMLAH BIAYA TETAP & & & & 194.167 & & & \\
\hline & JUMLAH BIAYA (B +C) & & & & 36.234.167 & & & \\
\hline & TOTAL BIAYA (B+C) & & & & 36.234 .167 & & & \\
\hline \multirow{2}{*}{\multicolumn{9}{|c|}{ PENDAPATAN }} \\
\hline & & & & & & & & \\
\hline & Harga Jual ukuran silet (Rp/Ekor) & & & & 550 & & & \\
\hline & Jumlah Produksi per siklus 2 bulan (ekor) & & & & 77.952 & & & \\
\hline & PENJUALAN (Rp) & & & & 42.873 .600 & & & \\
\hline & LABA KOTOR (Rp) & & & & 6.639 .433 & & & \\
\hline & BEP (EKOR) & & & & 65.880 & & & \\
\hline & BEP (Rp) & & & & 465 & & & \\
\hline & PAY BACK PERIOD (Tahun) & & & & 0,2 & & & \\
\hline & $\mathrm{R} / \mathrm{C}$ ratio & & & & 1,183236816 & & & \\
\hline
\end{tabular}

Tabel 3. Analisis usaha perbenihan ikan gurame di bak beton dengan sistem pergantian air 30\% secara berkala.

Table 3. Business analysis of giant gouramy hatchling in a concrete pond with $30 \%$ water change system with regular intervals

\begin{tabular}{|c|c|c|c|c|c|c|c|c|}
\hline A & INVESTASI & Jumlah & Satuan & harga & jumlah & $\begin{array}{c}\text { umur } \\
\text { ekonomis } \\
\text { (tahun) }\end{array}$ & $\begin{array}{c}\text { penyusutan } \\
/ \text { tahun }\end{array}$ & $\begin{array}{c}\text { penyusutan/ } \\
\text { siklus }\end{array}$ \\
\hline 1 & Pembuatan bak beton uk $4 \times 3 \times 0.5 \mathrm{~m}$ & 1 & unit & 1.650 .000 & 1.650 .000 & 10 & 165.000 & 27.500 \\
\hline 2 & Instalasi pipa dan asesoris & 1 & set & 5.000 .000 & 5.000 .000 & 5 & 1.000 .000 & 166.667 \\
\hline & JUMLAH INVESTASI & & & & 6.650 .000 & & 1.165 .000 & 194.167 \\
\hline B & BIAYA TIDAK TETAP & Jumlah & Satuan & harga & jumlah & & & \\
\hline 1 & Larva Gurame & 134.400 & ekor & 200 & 26.880 .000 & & & \\
\hline 2 & cacing Sutera & 224 & $\mathrm{~kg}$ & 40.000 & 8.960 .000 & & & \\
\hline 3 & obat-obatan & & paket & 200.000 & 200.000 & & & \\
\hline & JUMLAH BIAYA TIDAK TETAP & & & & 36.040 .000 & & & \\
\hline & & & & & & & & \\
\hline C & BIAYA TETAP & Jumlah & Satuan & harga & jumlah & & & \\
\hline 1 & Penyusutan & & siklus & 194.167 & 194.167 & & & \\
\hline & JUMLAH BIAYA TETAP & & & & 194.167 & & & \\
\hline & JUMLAH BIAYA $(B+C)$ & & & & 36.234 .167 & & & \\
\hline & TOTAL BIAYA (B+C) & & & & 36.234 .167 & & & \\
\hline & & & & & & & & \\
\hline & PENDAPATAN & & & & & & & \\
\hline & Harga Jual ukuran silet (Rp/Ekor) & & & & 550 & & & \\
\hline & Jumlah Produksi per siklus 2 bulan (ekor) & & & & 69.888 & & & \\
\hline & PENJUALAN (Rp) & & & & 38.438 .400 & & & \\
\hline & LABA KOTOR (Rp) & & & & 2.204.233 & & & \\
\hline & BEP (EKOR) & & & & 65.880 & & & \\
\hline & BEP (Rp) & & & & 518 & & & \\
\hline & PAY BACK PERIOD (Tahun) & & & & 0,2 & & & \\
\hline & $\mathrm{R} / \mathrm{C}$ ratio & & & & 1,060833008 & & & \\
\hline
\end{tabular}




\section{BAHASAN}

Pemeliharaan benih ikan gurame dengan menggunakan sistem resirkulasi (Wadah I) menunjukkan respon yang signifikan. Hal tersebut dikarenakan suhu pada Wadah I lebih stabil jika dibandingkan dengan perlakuan yang lainnya. Nilai suhu pada Wadah I berkisar antara 29,7-30, $1^{\circ} \mathrm{C}$ sesuai untuk mendukung kehidupan benih ikan gurame. Menurut BSN (2000a; 2000b), benih ikan gurame dapat hidup baik pada suhu 25$30^{\circ} \mathrm{C}$. Nilai suhu yang stabil pada Wadah I karena ditempatkannya heater (pemanas) pada kolam reservoir, sehingga suhu pada media pemeliharaan sistem resirkulasi dapat lebih terjaga stabil.

Nilai $\mathrm{pH}$ yang diperoleh selama masa pemeliharaan berkisar antara 5,87,8. Secara garis besar, hasil pengukuran pH pada penelitian ini sudah sesuai dengan pendapat dari Boyd (1982) yang menyebutkan bahwa nilai $\mathrm{pH}$ yang mematikan bagi ikan yaitu kurang dari 4 dan lebih dari 11. Kondisi air yang mendukung kelangsungan hidup organisme akuatik terutama ikan menurut PP No. 82 (2001) yaitu berkisar 6-9. Ikan dapat bertahan hidup di perairan dengan derajat keasamaan yang agak asam $(\mathrm{pH}$ rendah) sampai di perairan yang basa $(\mathrm{pH}$ tinggi) dengan $\mathrm{pH}$ 5-9 (Prihartono, 2004). Akan tetapi, Handajani (2006), menyebutkan $\mathrm{pH}$ yang baik untuk ikan gurame antara 6-8,5 dan untuk pertumbuhan optimal pada $\mathrm{pH}$ 7-8, sehingga hasil pengukuran $\mathrm{pH}$ yang diperoleh sudah baik namum belum optimal untuk mendukung kehidupan benih ikan gurame. Hal ini diakibatkan fluktuasi $\mathrm{pH}$ yang tidak terkendali dengan baik.

Hasil pengukuran DO pada pemeliharaan benih ikan gurame dengan sistem resirkulasi (Wadah I) memberikan hasil yang terbaik. Nilainya berada pada kisaran 6,1-7 ppm sesuai untuk menunjang kehidupan benih ikan gurame. Hal ini sesuai dengan pendapat dari Boyd (1982), kandungan DO yang baik seharusnya 5 ppm atau lebih, tetapi ada batasan bahwa DO < 1 ppm mematikan jika dibiarkan lama, 1-5 ppm ikan bertahan hidup, reproduksi rendah dan pertumbuhan lambat, sedangkan DO > 5 ppm ikan tumbuh normal dan bereproduksi. Tingginya nilai DO pada Wadah I disebabkan oleh aktivitas filtrasi yang dapat menjebak buangan hasil sisa metabolisme dan pakan yang tidak termakan serta partikel organik lainnya yang dapat menurunkan kadar oksigen terlarut dalam media pemeliharaan.

Wadah I (sistem resirkulasi) memberikan hasil yang terbaik terhadap kandungan amoniak. Hasil ini penting, karena amoniak yang terlalu tinggi (melebihi ambang batas) dapat membahayakan kehidupan ikan gurame yang dipelihara karena gas amoniak ini bersifat toksik atau beracun. Kandungan amoniak yang dapat ditoleransi oleh Ikan gurame adalah $<1 \mathrm{mg} / \mathrm{L}$ (Jumaidi et al., 2017).

Wadah I menghasilkan kandungan amoniak yang paling rendah. Hal tersebut diduga akibat adanya proses penyaringan air secara terus menerus sehingga kemungkinan kecil bagi bahan organik untuk membusuk dan menimbulkan adanya gas amoniak dalam media pemeliharaan. Wadah II yang menggunakan sistem air mengalir dimungkin akibat adanya aliran air secara terus menerus menyebabkan waktu tinggal dari bahan organik yang sebentar sehingga memperkecil kemungkinan pada bahan organik untuk mengendap dan membentuk gas amoniak. Wadah III yang menggunakan sistem pergantian air secara berkala diduga akibat adanya pergantian air yang secara rutin dilakukan ini menyebabkan bahan organik tidak mempunyai kesempatan waktu untuk membentuk gas amoniak dalam media pemeliharaan. Akan tetapi, dilihat dari hasil pengukurannya dapat dilihat bahwa Wadah I menunjukkan hasil yang lebih baik dibandingkan dengan perlakuan yang 
lainnya. Hal ini ditandai oleh rendahnya kadar amoniak dalam air dan stabilnya hasil pengukuran.

Padat tebar selama penelitian juga memberikan pengaruh terhadap laju pertumbuhan bobot harian ikan gurame. Seiring dengan meningkatnya padat tebar dibandingkan dengan media pemeliharaannya, maka laju pertumbuhan bobot harian semakin menurun (Putri et al., 2012). Selain itu, peningkatan padat penebaran menyebabkan ruang gerak bagi ikan menjadi sempit yang akhirnya menimbulkan stres.

Hasil pengamatan pada ABW seperti terlihat pada Gambar 6 diduga terjadi akibat adanya efisiensi penggunaan pakan selama waktu pemeliharaan pada Wadah I yang lebih efisien. Pertambahan bobot ikan berhubungan dengan nilai efisiensi pakan, bila laju pertambahan bobot harian meningkat maka pakan yang diberikan dapat dimanfaatkan seefisien mungkin untuk pertumbuhan ikan, sehingga nilai efisiensi juga meningkat. Menurut Elpawati et al. (2015), pada umumnya ikan kurang mampu memanfaatkan karbohidrat. Ikan yang bersifat karnivora dapat memanfaatkan karbohidrat optimum 10-20\% dan ikan omnivora pada tingkat $30-40 \%$ dalam pakan. Oleh karena itu, dengan adanya penambahan bahan yang dapat membantu menguraikan karbohidrat dalam pakan. Pertumbuhan ikan juga dipengaruhi oleh beberapa faktor yaitu genetik, hormon, kelamin dan lingkungan.

Wadah I memberikan hasil yang lebih tinggi terhadap SGR. Hal tersebut diduga akibat dari jenis pakan yang diberikan atau serapan nutrisi yang dapat diterima oleh tubuh organisme akibat kondisi kualitas air pada Wadah I yang lebih stabil, sehingga energi dari pakan yang terserap digunakan untuk pertumbuhan. Pertumbuhan merupakan pertambahan ukuran panjang atau berat dalam suatu waktu (Verawati et al., 2015). Pertumbuhan ikan erat kaitannya dengan ketersediaan protein dalam pakan.
Hasil pengukuran SR pada Wadah I sebesar 94,98\% merupakan hasil yang lebih tinggi daripada Wadah II $(55,97 \%)$ dan Perlakuan 3 (53,39\%). Hal tersebut diduga akibat dari kondisi kualitas air pada media pemeliharaan yang stabil pada Wadah I jika dibandingkan perlakuan lainnya. Kelangsungan hidup benih ikan gurame dipengaruhi oleh kematian. Kematian pada ikan dapat disebabkan oleh rendahnya kualitas air, penyakit, serangan predator, fisika kimia perairan dan kegagalan memperoleh makanan (Jumaidi et al., 2017). Tingginya nilai SR pada Wadah I dibanding perlakuan yang lain dapat disebabkan oleh kandungan oksigen yang tinggi dan suhu yang stabil pada media pemeliharaan sistem resirkulasi. Lebih lanjut dikatakan oleh Hanafiah (2005), faktor-faktor yang mempengaruhi kadar oksigen $\left(\mathrm{O}_{2}\right)$ dalam perairan secara umum merupakan konsekuensi terhambatnya aktivitas akar tumbuhan dan mikrobia, serta difusi yang menyebabkan naiknya kadar $\mathrm{CO}_{2}$ dan turunnya kadar $\mathrm{O}_{2}$.

Investasi untuk usaha perbenihan gurame dengan sistem resirkulasi memerlukan investasi yang lebih besar yakni Rp33.600,00 jika dibandingkan dengan kedua sistem lain yakni Rp6.650.000,00. Dampak dari nilai investasi ini adalah terhadap nilai payback period adalah dengan sistem resirkulasi lebih lama dibanding kedua sistem lain yaitu $1,5: 0,2$ : 0,2. Namun, untuk optimalisasi sarana produksi, biaya operasional sistem resirkulasi memerlukan biaya yang lebih kecil dibanding kedua sistem lain yakni Rp11.080.000,00 : Rp36.234.167,00 : Rp36.234.167,00.

Nilai jual produk benih gurame dari perbenihan gurame dengan sistem resirkulasi juga memiliki nilai lebih tinggi jika di banding nilai jual benih gurame dari hasil perbenihan dengan sistem di bak beton yakni Rp800,00 : Rp550,00. Hal ini disebabkan ukuran akhir benih gurame yang dihasilkan dari sistem resirkulasi 
lebih besar pada periode yang sama dibanding kedua sistem lain.

Laba yang diperoleh dari usaha perbenihan ikan gurame dengan sistem resirkulasi lebih besar dibanding dengan laba dari kedua sistem lain yakni Rp10.531.111,00 : Rp6.639.433,00 : Rp2.204.233,00. Demikian juga dengan $R C$ ratio dimana $R C$ ratio perbenihan ikan dengan sistem resirkulasi lebih baik yaitu 1,85 . Nilai BEP terendah terdapat pada usaha perbenihan resirkulasi dengan nilai Rp430,00 dibanding nilai BEP pada kedua sistem lain yaitu Rp465,00 dan Rp518,00.

\section{SIMPULAN}

Pemeliharaan benih ikan gurame menggunakan sistem resirkulasi memberikan pengaruh pada peningkatan kualitas air (suhu, DO, dan amoniak), dan angka kelulushidupan benih ikan gurame (average daily growth, average body weight, specific growth ratio, survival rate). Sistem resirkulasi memberikan hasil paling baik dibandingkan dengan sistem pemeliharaan tanpa resirkulasi.

Analisis usaha perbenihan ikan gurame menggunakan sistem resirkulasi menghasilkan keuntungan yang tinggi sehingga layak secara ekonomi, meskipun memerlukan biaya investasi yang lebih tinggi daripada sistem pemeliharaan tanpa resirkulasi.

\section{DAFTAR PUSTAKA}

Boyd, C.E. (1982). Water Quality Management For Pond Fish Culture. Elsevier Scinetific Publishing Company Amsterdam. New York.

[BSN] Badan Standar Nasional Indonesia. (2000a). Standar Nasional Indonesia Nomor 01-6485.2-2000 tentang Benih Ikan gurame (Ospronemus gouramy, Lac) Kelas Benih Sebar. BSN Indonesia.

(2000b). Standar Nasional Indonesia Nomor 01-
6485.3-2000 tentang Produksi Benih Ikan gurame (Ospronemus gouramy, Lac) Kelas Benih Sebar. BSN Indonesia.

Elpawati, Pratiwi, D. R., \& Radiastuti, N. (2015). Aplikasi Effective Microorganism 10 (EM10) Untuk Pertumbuhan Ikan Lele Sangkuriang (Clarias gariepinus va. Sangkuriang) di Kolam Budidaya Lele Jombang, Tanggerang. Jurnal Biologi, 8 (1): 6-14.

Hanafiah, K. A. (2005). Dasar-Dasar Ilmu Tanah. PT. Raja Grafindo Persada, Jakarta.

Handajani, H. (2006). Pengujian Hormon Metiltestoteron Terhadap

Keberhasilan Monosex Jantan Ikan Gurame (Osphronemus gouramy). Jurnal Protein, 13 (1): 63-72.

Jumaidi, A., Yulianto, H., \& Efendi, E. (2017). Pengaruh Debit Air terhadap Perbaikan Kualitas Air pada Sistem Resirkulasi dan Hubungannya dengan Sintasan dan Pertumbuhan Benih Ikan Gurame (Oshpronemus gouramy). Jurnal Rekayasa dan Teknologi Budidaya Perairan, 5 (2): 587-596.

Nugroho, M. H. (2008). Analisis Pendapatan dan Faktor-Faktor yang Mempengaruhi Hasil Produksi Pembenihan Ikan gurame Petani Bersertifikat SNI. Skripsi. Eksistensi Manajemen Agribisnis. Fakultas Pertanian. Institut Pertanian Bogor. Bogor.

Prihartono, R. E. (2004). Permasalahan gurame dan solusinya. Penebar Swadaya. Depok.

Putri, F. S., Hasan, Z., \& Haetami, K. (2012). Pengaruh Pemberian Bakteri Probiotik pada Pelet yang Mengandung Kaliandra (Calliandra calothyrsus) terhadap Pertumbuhan Benih Ikan Nila. Jurnal Perikanan dan Kelautan, 3 (4): 283-291.

Verawati, Y., Muarif, \& Mumpuni, F. S. (2015). Pengaruh Perbedaan Padat Penebaran Terhadap Pertumbuhan 
PELAGICUS: Jurnal IPTEK Terapan Perikanan dan Kelautan

Volume 2 Nomor 1: 23-35, Januari 2021

dan Kelangsungan Hidup Benih

Ikan gurame (Osphronemus

Gouramy) pada Sistem Resirkulasi.

Jurnal Mina Sains, 1 (1): 6-12. 